
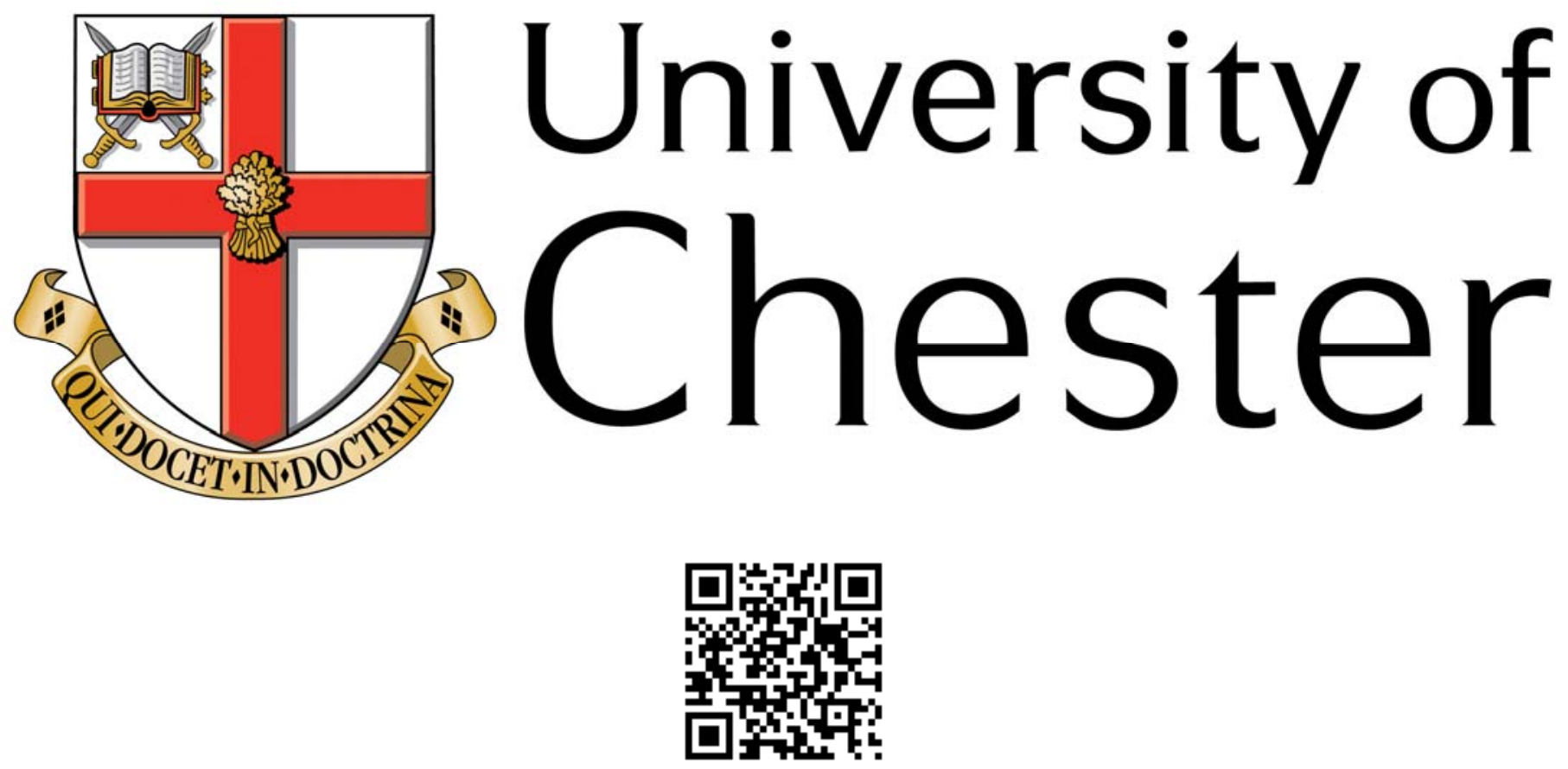

This work has been submitted to ChesterRep - the University of Chester's online research repository

\title{
http://chesterrep.openrepository.com
}

Author(s): Celia Deane-Drummond

Title: Theology and the culture of the sciences

Date: 2000

Originally published in: New Blackfriars

Example citation: Deane-Drummond, C. (2000). Theology and the culture of the sciences. New Blackfriars, 81(947), 36-46

Version of item: Author's post-print

Available at: http://hdl.handle.net/10034/14634 


\section{Theology and the Culture of the Sciences}

\section{Celia Deane-Drummond}

The idea that theology might have something to say to science, especially if we see this as one of its responsibilities, might seem to us to be an odd question to ask. Ever since C.P. Snow proposed the idea of the 'two cultures', the impression of many, apart from those with a keen interest in interactions between science and religion, is that sciences are best left to their own devices. It seems obvious, at first sight, that it is primarily in the realms of history, language, literature, art and music that theology can find welcome dialogue partners. In popular culture, too, there is a residual memory that over-zealous religious fanatics in some way constricted science. The stories of conflict between Thomas Huxley and Bishop Wilberforce, Galileo and the Holy See, have become inflated into mythologies of distrust and suspicion. The fact that the real historical accounts show many more nuances than this is important to establish, but is not really the point I am making here. Rather, I am suggesting that we have become so used to seeing the two areas of theology and science as separate, that we fail to notice in what ways the culture we live in is also one shaped by science, and that science itself is a profoundly cultural activity.

The temptation for those engaged in the dialogue between science and religion is simply to examine the particular discoveries in science and then discuss their implications for theology. While this can take us some way in the process of mutual understanding, what tends to happen is that science becomes the active partner, while theology is merely the passive recipient of what science is discovering. John Polkinghorne, who has done more than anyone to foster links between the two disciplines in a publicly responsible way, insists that theology needs to be consistent with the discoveries of science.(1) Such 
interactions are clearly valuable for those who find it hard to believe in the doctrines of the church, while admitting the truths of science. Writing of this type can be an apologetic both for science and the church. Yet while it is true that theologians need to have some awareness of the discoveries of science, it seems to me that theology can play a much more active role in the debate as well.

Nicholas Lash suggests that in science and technology, our 'ingenuity has outstripped our wisdom'.(2) This implies that science alone has failed to take adequate responsibility for its own applications. However, even a veiled criticism of this type is likely to be met with hostility by the scientists themselves. I will argue in this paper that fruitful questions to ask are: In what way is science contributing to a particular culture? and How might theology contribute to a reshaping of this ethos? Further, I suggest that once we understand science as a profoundly human activity, then dialogue with other areas of knowledge, including theology, becomes possible. Moreover, it seems to me that the responsibility of all theologians is to have some awareness of the activities of science at the cultural level.

\section{Facts and values}

We seem to have come a long way from seeing theology as the 'queen of the sciences', where all knowledge was in some sense united under an overarching cosmology of God, humanity and nature in an ordered universe. Even post-modernism, which relies on a hermeneutics of suspicion, is still in some sense a child of modernity. The theoretical physicists Alan Sokal and Jean Bricmont roundly rejected the attempt by French postmodem philosophers, including among others, Irigaray, Lacan and Lyotard to support their views by drawing on their mathematical formulations.(3) They insisted that their work was 'abused' and distorted, enlarged to support speculations that were completely unrelated to 
the original ideas. They even went as far as publishing a hoax article in an American journal called Social Text, deliberately offering a parody of the new physics as simply a linguistic construct. It seems likely that the French theorists were unjustified in their use of science. However, I will show later that some scientists are quite adept at enlarging their science into myths. One possible explanation for the hostility of Sokal and Bricmont is that it seemed to them to break what has become a sacred code, that science is objective. Ironically, perhaps, the fact/value distinction is itself beginning to break down with the advent of quantum physics. Those attuned to this new physics recognize that all our observations affect, in some way, what is observed, the world is one of probabilities. This does not mean that facts in the new physics suffer from the same foibles as values, as many social scientists would have us believe. For practical purposes we still operate according to a Newtonian system, the laws of gravity and motion still have relevance to our everyday existence. An argument can be made for an expansion of Newtonian physics to include more recent research, rather than a simplistic replacement of one by another. In this sense the mythology of the split between facts and values survives, albeit in a more muted form.

Rather than simply showing that there are values in science, a more interesting question is to ask, why is it necessary for many working scientists to hold this view of value-neutrality? I suggest that it is in discovering some of the reasons for this belief that core aspects of the culture of the sciences come into view. The origin of the idea that science is value-free can be traced to four key factors:(4)

1. Ideal of theoria. This is based on Aristotelian principles that science must be detached from practical affairs. In this sense science becomes value-free, as it is more about principles and theory than practice. Francis Bacon was a champion of 
the idea of the utility of science and the usefulness for human benefit This tended to weaken the distinction between theory and practice in a way that continues even today.

2. Scientific method. A core goal of scientific method was to achieve objectivity, with no traces of influence from 'bias' that might be caused by moral or other qualities, such as religious beliefs. Such beliefs would, it is argued, distort any knowledge gained. As I hinted earlier, the recognition that pure objectivity is ultimately impossible in science as well, as shown by modern physics and some areas of biology, such as ecology, has failed to dent the quest, at least, for objective knowledge.

3. The nature of value. Prior to the Copernicus' revolution, the ancients believed that value is God-given, built into the structure of the cosmos. In science the idea that value is created by human agency, rather than in raw nature, is presupposed. Scientists assume an instrumental approach to value, in other words that value is measured by its usefulness to humanity. Accordingly, the world of nature becomes value-free, or 'disenchanted', and no longer organized according to natural harmonies. Science is neutral because nature is neutral, it is just an exploration of the efficient causes of laws in nature, without any reference to the idea of purpose.

4. The security of knowledge. The philosopher, Euripides believed that knowledge of nature was 'safe', that is it was free from politics and ethics. Francis Bacon conferred that knowledge of nature was neutral and a Christian understanding of the Fall is related to the knowledge of good and evil. He identified moral knowledge as 'dangerous'. In spite of his protestations for neutrality, he envisaged science as the herald to a new Utopia on earth. By the nineteenth century a much narrower conception of science had emerged, where science was specialized and 
fragmented into numerous sub-disciplines. However, even as the bulk of science became the servant of industry, the longing of many scientists for purity of knowledge continued, especially in the universities.

Given these possible reasons for scientists wishing to hold on to the ideal of valueneutrality, it is worth considering how such a proposal could serve to promote the interests of science. It is too simplistic to consider that scientists do not recognize the importance of values themselves, rather they believe that in providing a detached approach to the problem this could be of service in arbitrating between opposing groups in legal or social disputes.

\section{Encultured science}

The rise of modern experimental science is a curiously Western phenomenon. Nonetheless, few would doubt that in pre-modern times the Oriental nations were responsible for considerable advances in science. Needham's extensive historical research on the relationship between science and society in the East and West suggests that it was the prevailing social, intellectual and economic conditions of Renaissance Europe that were primarily responsible for the breakthroughs in science occurring in the West.(5) The experimental science that flowered in Europe seemed too interventionist to be philosophically respectable. For the purposes of this article I will be focusing on the dialogue between theology and Western science, rather than other versions that have been proposed, such as Islamic science.

While it is too simplistic to suggest that Christianity was responsible for the emergence of science in the West, it certainly did not inhibit its growth. It is well known that many of the 
early scientists were also Christians, such as the physicist Isaac Newton and the botanist John Ray. Amos Funkenstein looks back to a time when science and religion still coexisted in the seventeenth century synthesis. He highlights the way these writers tried to fuse the Scholastic desire for purification of language about forms, with the Renaissance ideal of homogeneity in nature. The result was a univocal language of science and an objectification of knowledge.(6) Lash believes that this ideal led to an effective dismissal of other ways of reading texts, a rejection of narrative, poetry and paradox. He identifies the 'spectatorial' model of humanity's relationship with nature as the most significant factor that reduces other ways of interpreting the world.(7)

While Lash's analysis is worth taking seriously, I believe that there were other social factors that contributed to the elevation of science as a way of knowing. Funkenstein suggests that the most significant change in the seventeenth century was the belief that knowledge could be acquired through construction, through doing, a factor that Lash seems to ignore.(8) This idea of construction is significant as it opens the way for experimental science in a way that pure observation did not. Although many of these writers confined the concept of construction of nature to God and only allowed humans to construct their social reality, it was only a short step before the idea took hold that all knowing is related to experimental pragmatism. While observation is passive and more akin to contemplation, popular in the medieval world, doing is active and allows for experimental human intervention that is necessarily characteristic of modern science. I suggest that in addition to these philosophical factors, the practical success of science tended to support and reinforce its ideals. The implication of this analysis is that science became not just enculturated in the Western world, but a shaper of that culture as well. Yet we might ask ourselves if this model still needs some refinement. The practice of science 
is not as detached as it seems, scientists work in communities and develop their own narratives, some might even suggest their own wisdom. Before the modern shift to a scientific cultural ethos is cast too quickly in a negative light, it is worth teasing out elements of what the culture of the sciences might be like.

\section{Exploring elements of scientific culture}

I have already examined in some detail one aspect of scientific culture that has begun to break down, namely the claim to be value-free. Other, related, claims are that science is transcultural and apolitical. It would be foolish to suggest that certain experiments in science cannot be repeated in different cultural and political settings, though it is equally fallacious to suggest that science policy is an entirely neutral affair. Scientists themselves are now beginning to acknowledge this as well. While in Britain the 1960s and 1970s political debates were primarily about the regulatory bodies that controlled access to funds, by the 1980s, under the Thatcher government, the key criterion was commercial utility, an attitude that is still pervasive today. Finally, the 1990s debates are primarily over survival, with the creation of a 'superleague' of 'research' universities.(9) Given this squeeze on funding, it is hardly surprising that scientists in universities have turned more and more to funding from the military or commercial sectors, with their own particular vested interests. Scientists in the 1990s are now much more on the defensive, lacking their earlier confidence. Yet there are elements of traditional ideals of science that still persist, in spite of the increased fragmentation and specialisation.

While political and other pressures on scientists will diminish their interest in seeking truth as they perceive it in the natural world, it is important to acknowledge the strength of this claim. Hanbury Brown describes science in the following way: 
it acts as our essential link with reality and if we fail to maintain this link, then there is no longer any 'nature's truth', nor is there 'public truth', there is only 'your truth' and 'my truth' and we are in danger of losing the distinction between fact and fiction and science and magic.(10)

Brown's claim that science is an arbiter of truth can easily slide into scientism. A check on such a development emerges in the New Physics. However, the recognition in quantum theory that the observer conditions all observations, does not lead to the opposite extreme of subjective truth. Rather, any objectivity needs to be qualified and not claimed to be final in any sense. This leads to more searching for what David Deutsch has described as the Fabric of Reality.(11) Richard Dawkins points out that for scientists fiddling data or lying about the results is, in scientific practice, the one unforgivable sin. For him there is 'something almost sacred about nature's truth'.(12) However, before the search itself is dismissed, it seems to me that such ideals, however misplaced, were necessary in order to foster its achievements. As Polanyi has reminded us, science involves a personal, committed way of approaching the world that bears some resemblance to a faith commitment. Also as Pope John Paul suggests, every truth presents itself as a universal claim, even if it is not the whole truth. He even defines the human being as 'the one who seeks the truth'. Furthermore, for scientists it is the personal confidence that an answer can be found that spurs on the search.(13) The euphoria of the nineteenth and early twentieth centuries about the unlimited possible benefits of science has now faded, but few would wish to live in a world without clean water, electricity, antibiotics and medicines that make human life possible. The search for truth in the theological sense is related to answers to ultimate questions, but also in the context of a human community of faith. While the ultimate Truth for a Christian is revealed in Jesus Christ, this is not opposed to 
the truths found in the natural order of things discovered by scientists. However, not all claims to truth in science are compatible with the Christian vision of Truth.

Another aspect of the culture of science that is easy to omit is that of wonder. It is curiosity about life, as well as the search for truth, that often drives scientists in their search. In the seventeenth and eighteenth centuries the real interest in science came from sheer enjoyment of its practice. This was a technologically innocent world, having an exuberance that is hard, perhaps, for us to imagine with our popular image of scientists today as terribly serious. It becomes much harder, though I would argue not impossible, to sustain this vision once experimental techniques are adopted. In other words it is the particular way of looking that is significant. Is it a looking with a view to control, or is it a tuning in to the natural world through careful listening?

It is, perhaps, surprising that Richard Dawkins, who is one of the champions of the mechanistic ways of looking at the world, has also declared recently that science is the ultimate source of wonder. He admits that this is deliberate attempt on his part to shake off the image of someone who has piped too long to the tune of the Selfish Gene. For him: "The feeling of awed wonder that science can give us is one of the highest experiences of which the human psyche is capable. It is a deep esthetic passion to rank with the finest that music and poetry can deliver'.(14) He suggests that science helps us break out of the numbness of the familiar by opening up new worlds in a way that leads to wonder. Related to the idea of wonder is the search for beauty, which is connected with an understanding of the truths of science. In as far as he points to the wonders of creation his book is a kind of proto-theology. However, it is a deliberate attempt to redirect those who search for poetry and mysticism in religion to science and science alone. His affirmation of the role of 
imagination in science is not new. What does seem strange is the way he aims to redirect all imagination to science itself. It is here that his sense of wonder is ultimately problematic, as it seems to point to the self-glorification of human activities in science alone.

Modern experimental science is often stereotyped as viewing nature as a machine, rather than an organism. Feminist critics of science, such as Carolyn Merchant, have been particularly critical of the machine metaphor, believing that this led to both the desacralisation and 'death' of nature.(15) She identifies science, epitomized in the figure of Francis Bacon, as responsible for the domination of both nature and women. However, before concluding too rapidly that a return to an organic approach is all that is required three issues need to be born in mind. The first is that without some sense of nature as 'other', which is characteristic of the Judeo-Christian faith, I have my doubts if any of the benefits of science would have been realized. The second is that one of the key characteristics of experimental scientific method is its claim to search for causes in nature, rather than through reference to a Scholastic 'final cause'.(16) The third issue is that it is too simplistic to think of science as just treating nature as a machine. In practice both the romantic and more mechanistic approaches to science have existed side by side, though it was the mechanistic view that attracted the most institutional support.(17) The organic approach has its dangers, too, in particular that associated with fascism. The holistic approach to science was very popular in Germany at around the time of the Third Reich. Its positive contribution was a fostering of multilevel discourses. However, the fear of the fascism that this seemed to support effectively dampened this movement in scientific circles. I am not arguing that organic approaches to nature are necessarily fascist, rather that there are dangers in both extreme versions of mechanism or organicism. Replacing 
mechanistic philosophy with an equally problematic holism does not take us very far.

\section{Theology and scientism}

Scientism may take different shapes. A common one is that science is the ultimate source of knowledge. The positivist claim that everything is within the power of science still lingers on today, in writing such as that of Peter Atkins, so that he claims that 'there is no question whose answer is not attainable by science.(18) Deutsch, like Dawkins, argues that the basis of life is molecular, so that the organism is the environment of the replicators known as genes.(19) For Deutsch life is a 'side effect' of the macroscopic physical processes operating at the molecular level. However, he cannot bring himself to believe that life will ultimately be meaningless, as the logic of such a view might suggest. Rather, if we assume a closed universe, that is a universe ending in a 'Big Crunch', we are only a tenth of the way through history from the early 'Big Bang'. He concurs with Frank Tipler, who suggests a infinite future for intelligent life.

Frank Tipler's portrait is interesting as he uses theological language to support his views.(20) His position is a curious one, in that while claiming to be an atheist, he wraps his physical models in the language of God. He suggests that the future does make an imprint on the present, since the physical laws do not change with time. However, it is by no means clear how this might be an imprint from ahead, in the way a Christian understanding of the parousia would suggest. Furthermore, immortality for Tipler seems to mean simply information processing. Such processing is dependent on increasing availability of energy as the 'final singularity' approaches. While the proper time will inevitably come to an end in a closed universe, he suggests that it could exist for infinite subjective time. For him distinctions between living and non-living no longer exist, until life 
so pervades and controls the system that it reaches what he terms the 'Omega Point'. While he borrows the language from Teilhard de Chardin, he modifies his theology in important ways. Teilhard understood God as immanent in an evolving universe and yet transcendent through a form of pan-en-theism, but Tipler cannot ultimately avoid pantheism. For Tipler such an 'Omega Point' means total omnipresence and omnipotence and omniscience, the final convergence of space and time through which a new resurrection is made possible, one that is envisaged as the Person, who is God. Such a resurrection of past humanity seems to be in the forms of light rays, extracted as information to be used at the very instant of the Omega Point.(21)

What is left of the reality of human life in such speculations? If this is a scientific eschatology, it is an apocalypse indeed. Yet it is one with no real hope of transformation and new life. It is in stark contrast to the biblical view of the end where ultimately, following immense struggles, all creation is caught up in praise and worship of God. In the models of both Deutsch and Tipler, science has refused to let go of intelligence and turned this into a god to be perpetuated ad infinitum. Such pride is more likely to accelerate the fate of the destruction of the earth, rather than allow its perpetuation in the form of information. Far from being a cosmological vision of the future, it is one that rests ultimately with human abilities alone, even though such abilities are recast in theological language. In this it fosters the idea of control and domination of humanity over not just this earth, but far into the outer reaches of the galaxy as well.

Another shape that scientism may take is that it is the ultimate source of values. Richard Dawkins' thesis expressed in The Selfish Gene might, at first sight, give the impression that he locates our ultimate source of value in our genes alone.(22) However, to be more 
precise he argues that altruism is 'selfish' as far as genes that code for such behaviour is concerned, since evolution is dependent on conservation of particular genes. Mary Midgley's initial misunderstanding of this led to some bitter debate, though I think she is right to suggest that the language he uses is too suggestive of moral action to be contained in the way that he suggests. In the other words statements such as 'we are survival machines' are inevitably value-laden. Dawkins himself betrays certain weariness when he says recently: 'I am tired of being identified with a vicious politics of ruthless competitiveness, accused of advancing selfishness as a way of life'.(23) Rather, the Darwinian notion of nature 'red in tooth and claw' is a lifestyle that he believes we need to vehemently reject. He also rejects the idea of eugenics, though admits that science does not rule it out as a possibility. For him, nothing, not even human values, should deny science its possibilities.

Hence, while he denies that science is an ultimate source of values, he seems to contradict this by elevating the value of scientific knowledge. A second important thread to his work is his belief that science can discover the way values emerge and are transmitted in human communities. Such values evolve through a process of Darwinian natural selection. However, while natural selection led to the emergence of humans with large brains, our ability to think and have foresight means that we can act against what might seem to be the dictates of our genes. He introduces another concept, namely that of 'memes', which are cultural constructs passed between members of the human community. Such memes compete for survival and, like genes, only some survive. He calls this the 'science of values', that is a particular biological way of interpreting how values are passed from one generation to the next. With some irony he suggests that just as those who dismiss the claims of the Old Testament as a source of values, so too he is entitled to 
chose not to behave as one governed entirely by his genetic make up.(24) He admits that this leaves us in an 'ethical vacuum' and this is what we should admit to instead of claiming to gain our sense of value from a religious source.

It seems to me that even if biological research suggests that there is a biological component to altruism or even values, then this is not necessarily incompatible with Christian belief. We might chose to challenge its scientific basis by pointing to the fact that values emerge in a complex and intricate way in human culture in a way that only has a very tenuous link with genetics. Memes, in particular, sound like an over-extrapolation of what is known in evolutionary theory. It is when sociobiology is claimed to be the only explanation that it becomes particularly dangerous. While Richard Dawkins refuses to accept that he gains his values from science, he denies the possibility of any religious experience as having any value at all. It seems to me that to be logically consistent he would have to admit this as being a possibility, especially as the science on its own has left us in an 'ethical vacuum'. In addition, his system of priorities still come from scientific analysis, so it is more likely that his values are rooted in science as knowledge in general sense, even if they are not crudely identified with his particular hypothesis of the selfish gene.

It is ironical, perhaps, that a form of scientism as the ultimate basis for value also comes from those at the organic end of the scientific spectrum. I refer to the Gaia hypothesis of James Lovelock. I do not intend to discuss this hypothesis in detail, except to say that it has become a source of values for those wishing to re-construct a worldview on more ecological lines. The fact that the hypothesis itself is highly ambiguous ethically is a point ignored by many of its advocates. It is also surprising that Mary Midgley, who has actively 
campaigned against scientism in all its forms, seems to be quite ready to affirm Lovelock's approach as highly suggestive for philosophy and ethics.(25)

\section{Theology and the future of science}

So far I have argued that the relation between the sciences and culture is a highly dynamic one. Just as science is in some sense encultured in human experience, so too science fosters a particular ethos and way of looking at the world. A theological approach to this aspect of science suggests that while we may welcome some elements of a scientific ethos, others need to be treated with much more caution. In particular, we need to resist all attempts to make science the ultimate source of knowledge and values. It is no use just making the simple claim that science discovers the facts and others apply these in good or evil ways. Rather, the very questions that science sets itself to ask need to be considered in the light of the needs of the human community.

I am not suggesting that all science needs to be controlled by pragmatic aims, rather that the motivation for particular directions in science needs to be evaluated in defining science policy. Perhaps we need to recover something of the ancient idea of wisdom, where science was no longer disjointed from other human pursuits, but was part of a philosophical and theological framework. The methodology of science makes it hard for scientists themselves to undertake such a broadening of their vision. Yet if theology is to offer something to science it is surely this; an affirmation of its values of wonder, beauty, reason, truth and imagination, but at the same time a rejection of arrogance, closed mindedness and irresponsibility, especially in certain applications in technology. In the place of the 'ethical vacuum' left by biological science, theology can bring a framework for ethics. However, if nature alone is looked to as a source of ultimate value, it is bound to 
disappoint. In the words of Pope John Paul II, scientists need to:

continue their efforts without abandoning the sapiential horizon within which scientific and technological achievements are wedded to the philosophical and ethical values which are the distinctive and indelible mark of the human person.(26)

1 J. Polkinghorne, Scientists as Theologians: A Comparison of the Writings of Ion Harbour, Arthur Peacocks and John Polkinghorne, London: SPCK, 1996, 6.

2 N. Lash, The Beginning and End of Religion, Cambridge: Cambridge University Press, 1996, 78.

3 J. Bricmont and A. Sokal, Impostures Intellectuelles, Odite Jacob, 1997.

4 For discussion see R.N. Procter, Value-Free Science? Purity and Power in Modem Knowledge, Cambridge: Harvard University Press, 1991, 262-70.

5 J. Needham, The Grand Titration: Science and Society in East and West, London: Allen and Unwin, 1969, 190.

6 A. Funkenstein, Theology and the Scientific Imagination, Princeton: Princeton University Press, 1986, 41.

$7 \quad$ Lash, The Beginning and End of Religion, op. cit, 80.

8 Funkenstein, op. cit, 12, 297.

9 C.C. Rassam, The Second Culture. British Science in Crisis: The Scientists Speak Out, London: Aurum Press, 1993, 196-208.

$10 \mathrm{H}$. Brown, The Wisdom of Science: Its Relevance to Culture and Religion, Cambridge: Cambridge University Press, 1986,123.

11 D. Deutsch, The Fabric of Reality, London: Penguin, 1997.

12 R. Dawkins, 'The Values of Science and the Science of Values', in W. Williams, ed, The Values of Science, Oxford: Westview Press, 1999, 13-14.

13 Pope John Paul II, Faith and Reason, Encyclical Letter Fides et Ratio, London: Catholic Truth Society, 1998, 41-5.

14 R. Dawkins, Unweaving the Rainbow: Science. Delusion and the Appetite for Wonder, London: The Penguin Press, 1998, x.

15 C. Merchant, The Death of Nature: Women, Ecology and the Scientific Revolution, London: Wildwood House, 1980.

16 J. Beihe, ReThinking Ecological Politics, Boston: South End Press, 1991, 107-8.

17 J. Brooke and G. Cantor, Reconstructing Nature: The Engagement of Science and Religion, Edinburgh: T. \& T. Clark, 1998, 96.

18 P. Atkins, 'The Limitless Powers of Science', in J. Cornwell, ed., Nature's Imagination: The Frontiers of Scientific Vision, Oxford: Oxford University Press, 1995, 122-33.

19 Deutsch, op. cit., $171 \mathrm{ff}$.

20 See, F. J. Tipler, The Physics of Immortality: Modern Cosmology: God and the Resurrection of the Dead, Basingstoke: MacMillan, 1994.

21 F. Tipler, "The Omega Point as Eschaton: Answers to Pannenberg's Questions for Scientists', Zygon 24:2 (1989), 217-53, The Physics of Immortality, ibid., $220 \mathrm{ff.}$

22 R. Dawkins, The Selfish Gene, Oxford: Oxford University Press, 1989.

23 R. Dawkins, "The Values of Science and the Science of Values' in W. Williams, ed., The Values of Science, Oxford: Westview Press, 1999, 19.

24 Ibid., 35-7. 
25 M. Midgley, Utopias, Dolphins and Computers: Problems of Philosophical Plumbing, London: Routledge, 1996,149 ff.

26 John Paul II, Faith and Reason, op.cit, 152. 